\title{
PENGUNGKAPAN ISLAMIC SOCIAL REPORTING PADA INDEKS SAHAM SYARIAH INDONESIA
}

\author{
Ardiani Ika Sulistyawati \\ Fakultas Ekonomi Universitas Semarang \\ ardiani@usm.ac.id \\ Indah Yuliani \\ Fakultas Ekonomi Universitas Semarang \\ ardiani.ika2005@gmail.com
}

\begin{abstract}
Islamic Social Responsibility (ISR) is a measure of social responsibility implementation of Islamic banking which contains a compilation of items of CSR standards set by the Accounting and Auditing Organization for Islamic Financial Institutions (AAOIFI). This study aims to examine empirically and analyze the effect of firm size, profitability, leverage and board size to disclosure of Islamic social reporting. The research sample using purposive sampling where the sampling is based on certain criteria, obtained a sample 39 companies. Methods of data analysis used in this study using linear regression, t test, F test, classic assumption and the coefficient of determination.The results showed that the Board of Independent Commissioners significant and positive impact on the ISR Size. Other results show thay Profitability and Leverage no significant effect on ISR.
\end{abstract}

Keywords: company size, profitability, leverage, board size and disclosure of Islamic social reporting

AKUISISI : Jurnal Akuntansi dan Keuangan

Website : $\underline{\text { http: } / / w w w . f e . u m m e t r o . a c . i d / e j o u r n a l / i n d e x . p h p / J A ~}$

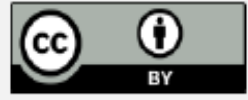

This is an open access article distributed under the terms of the Creative Commons Attribution 4.0 International License, which permits unrestricted use, distribution, and reproduction in any medium, provided the original work is properly cited.

\section{PENDAHULUAN}

Islamic Social Responsibility (ISR) merupakan tolak ukur pelaksanaan tanggung jawab sosial perbankan syariah yang berisi kompilasi item-item standar CSR yang ditetapkan oleh Accounting and Auditing Organization for Islamic Financial Institutions (AAOIFI). Indeks pengungkapan sosial untuk entitas islam (ISR) mengungkapkan hal-hal yang berkaitan dengan prinsip islam seperti transaksi yang sudah terbebas dari unsur riba, spekulasi dan gharar, serta mengungkapkan zakat, status kepatuhan syariah serta aspek-aspek sosial seperti sodaqoh, waqof, qordul hasan sampai dengan pengungkapan peribadahan di lingkungan perusahaan (Maulida dkk, 2014).

Pelaporan social syariah atau Islamic Social Reporting (ISR) masih bersifat sukarela, sehingga pelaporan CSR setiap perusahaan syariah menjadi tidak sama.Pelapoan yang tidak sama tersebut disebabkan tidak adanya standart yang baku secara syariah tentang pelaporan CSR syariah. Konsep CSR mulai berkembang di ekonomi syariah, hal ini terbukti semakin banyak perusahaanperusahaan yang menerapkan prinsip-prinsip syariah di setiap kegiatan bisnisnya yang diharapkan 
perusahaan tersebut dapat melakukan tanggung jawab social perusahaan secara islami. Perkembangan CSR dalam ekonomi islam juga berdampak pada meningkatnya perhatian masyarakat terhadap instansi-instansi atau lembaga syariah. Pasar modal syariah sebagai lembaga dan profesi yang berperan penting dalam meningkatkan pangsa pasar efek-efek syariah pada perusahaan-perusahaan ingin berpartisipasi dalam pangsa pasar syariah di Indonesia. Di Indonesia perkembangan pasar modal syariah diawali dengan dibentuknya Jakarta Islamic Index (JII). Jakarta Islamic Index ini hanya terdiri dari 30 saham syariah yang tercatat di Bursa Efek Indonesia (BEI). Namun, munculnya Indeks Sahan Syariah Indonesia (ISSI) akan menjadi acuan bagi investor untuk berinvestasi di saham syariah sekaligus menggambarkan kinerja seluruh saham syariah yang tercatat di BEI seta membantu menjelaskan kesalah pahaman masyarakat yang beranggapan bahwa saham syariah hanya terdiri dari 30 saham yang masuk dalam JII (www.idx.co.id).

Salah satu faktor yang mempengaruhi pengungkapan ISR adalah ukuran perusahaan. Ukuran perusahaan adalah karakteristik spesifik perusahaan yang hampir selalu digunakan untuk menguji tingkat pengungkapan sukarela (Putri dkk, 2014). Fakta ini dibuktikan dengan penelitian yang dilakukan Astuti (2014), Putri dkk (2014), Swastiningrum (2013), Lestari (2013) dan Widiawati (2012) menemukan bahwa ukuran perusahaan (size) berpengaruh positif terhadap ISR, dimana perusahaan yang memiliki ukuran perusahaan semakin besar biasanya akan mengungkapkan ISR lebih luas. Sedangkan penelitian yang dilakukan Purnasanti M dkk (2014) menemukan hasil ukuran perusahaan tidak berpengaruh signifikan terhadap ISR.

Profitabilitas juga mempengaruhi pengungkapan ISR. Teori stakeholders mendukung hubungan positif profitabilitas terhadap ISR. Teori ini menyatakan perusahaan bukanlah entitas yang hanya beroperasi untuk kepentingan sendiri namun harus mampu memberikan manfaat bagi stakeholdersnya. Makin powerful stakeholders, makin besar usaha perusahaan untuk beradaptasi (Putri dkk, 2014). Purnasanti M dkk (2014), Fr. Reni (2014), Lestari (2013), dan Widiawati (2012) menemukan bahwa pengaruh profitabilitas terhadap ISR berpengaruh signifikan. Namun dalam peneitian Astuti (2014), Putri dkk (2014) serta Swastiningrum (2013) menghasilkan bahwa profitabilitas tidak berpengaruh terhadap luas informasi pada pengungkapan ISR.

Leverage digunakan untuk mengukur kemampuan perusahaan dalam memenuhi seluruh kewajibannya kepada pihak lain. Rasio leverage menggambarkan sampai sejauh mana aktiva suatu perusahaan dibiayai oleh hutang. Manajemen dengan tingkat leverage yang tinggi akan mengurangi pengungkapan sosialnya demi menghindari pemeriksaan kreditur ( Swastiningrum, 2013). Penelitian Astuti (2014) menemukan bahwa Leverage berpengaruh positif terhadap pengungkapan ISR. Sedangkan penelitian Anggraini (2006) dan Swastiningrum (2013) menemukan bahwa tidak ada pengaruh leverage terhadap ISR.

Ukuran dewan komisaris yaitu jumlah anggota dewan komisaris dalam suatu perusahaan (Sembiring 2005 dalam Amirul Khoirudin, 2013). Semakin besar ukuran dewan komisaris, maka pengawasan akan semakin baik. Dengan pengawasan yang baik, maka diharapkan pengungkapan Islamic social reporting akan semakin luas karena dapat meminimalisir informasi yang mungkin dapat disembunyikan oleh manajemen. Hasil temuan penelitian yang dilakukan oleh Amirul Khoirudin (2013) menemukan bahwa ukuran dewan komisaris berpengaruh terhadap pengungkapan ISR sedangkan penelitian Lestari (2013) menemukan ukuran dewan komisaris tidak berpengaruh terhadap pengungkapan ISR.

Berdasarkan hasil penelitian-penelitian sebelumnya, Islamic Social Reporting merupakan hal yang penting bagi perusahaan-perusahaan syariahuntukmemenuhi ekspektasi dari para pemangku kepentingan,khususnya bagi para masyarakat muslim. Oleh sebab itu penulis melakukan studi untuk mengidentifikasi faktor-faktor apa saja yang mempengaruhi perusahaan-perusahaan 
syariah untuk mengungkapkan Islamic Social Reporting dalam laporan tahunannya pada perusahaan-perusahaan syariah yang terdaftar di Indeks Saham Syariah Indonesia (ISSI). Dengan demikian penelitian mengenai Islamic Social Reporting ini diharapkan dapat menjadi masukan yang baik agar dalam masa yang akan datang perusahaan-perusahaan syariah dapat menerapkan pengungkapan Islamic Social Reporting yang memadai sesuai dengan prinsip syariah.

\section{HubunganUkuran Perusahaan denganPengungkapan Islamic Social Reporting (ISR)}

Ukuran perusahaan adalah karakteristik spesifik perusahaan yanghampir selalu digunakanuntuk menguji tingkat pengungkapan sukarela (Putri dkk, 2014).Perusahaan yang besar biasanya memiliki aktivitas yang lebih banyak dan kompleks, mempunyai dampak yang lebih besar terhadap masyarakat, memiliki shareholder yang lebih banyak, serta mendapat perhatian lebih dari kalangan publik, oleh karena itu perusahaan besar cenderung mendapat tekanan yang lebih untuk mengungkapkan pertanggungjawaban sosialnya (Cowen et al., 1987 dalam Amran dan Devi, 2008).Fakta ini dibuktikan dengan penelitian yang dilakukan Astuti (2014), Putri dkk (2014), Swastiningrum (2013), Lestari (2013) dan Widiawati (2012) menemukan bahwa ukuran perusahaan (size) berpengaruh positif terhadap ISR,dimana perusahaan yang memiliki ukuran perusahaan semakin besar biasanya akan mengungkapkan ISR lebih luas. Sedangkan penelitian yang dilakukan Purnasanti M dkk (2014) menemukan hasil ukuran perusahaan tidak berpengaruh signifikan terhadap ISR.

H1 : Terdapat pengaruh yang positif dan signifikan antara ukuran perusahaan terhadap Pengungkapan Islamic Social Reporting (ISR)

\section{HubunganSikap Wajib Pajak denganPengungkapan Islamic Social Reporting (ISR)}

Profitabilitas juga mempengaruhi pengungkapan ISR.Teori stakeholdersmendukung hubungan positif profitabilitasterhadap ISR. Teoriini menyatakan perusahaan bukanlah entitas yang hanya beroperasi untukkepentingan sendiri namun harus mampu memberikan manfaat bagistakeholdersnya. Makinpowerful stakeholders, makin besar usaha perusahaanuntuk beradaptasi ( Putri dkk, 2014).Pengungkapan mengenai pertanggungjawaban sosial perusahaan mencerminkan suatu pendekatan perusahaan dalam melakukan adaptasi dengan lingkungan yang dinamis dan bersifat multidimensi. Hubungan antara pengungkapan tanggung jawab sosial perusahaan dan profitabilitas perusahaan telah diyakini mencerminkan pandangan bahwa reaksi sosial memerlukan gaya manajerial yang dilakukan oleh pihak manajemen untuk membuat suatu perusahaan memperoleh keuntungan (Bowman dan Haire, 1976 dalam Sembiring, 2003).Dari perspektif Islam, perusahaan harus bersedia untuk memberikan pengungkapan penuh tanpa melihat apakah perusahaan memberikan keuntungan atau tidak (Haniffa, 2002). Perusahaan dengan profiatabilitas yang lebih tinggi kemungkinan akan mengungkapkan informasi yang lebih dibandingkan perusahaan dengan profitabilitas yang kurang tinggi.Penelitian oleh Purnasanti M dkk (2014), Fr. Reni. Retno Anggraini (2014), Lestari (2013), dan Widiawati (2012) menemukan bahwa pengaruh profitabilitas terhadap ISR berpengaruh signifikan. Namun dalam peneitian Astuti (2014), Putri dkk (2014) serta Swastiningrum (2013) menghasilkan bahwa profitabilitas tidak berpengaruh terhadap luas informasi pada pengungkapan ISR.

H2 : Terdapat pengaruh yang positif dan signifikan antara profitabilitas terhadap Pengungkapan Islamic Social Reporting (ISR) 


\section{HubunganLeverage dengan Pengungkapan Islamic Social Reporting (ISR)}

Leverage digunakan untuk mengukur kemampuan perusahaan dalam memenuhi seluruh kewajibannya kepada pihak lain. Rasio leverage menggambarkan sampai sejauh mana aktiva suatu perusahaan dibiayai oleh hutang.Leverage digunakan untuk mengukur kemampuan perusahaan dalam memenuhi seluruh kewajibannya kepada pihak lain. Rasio leverage menggambarkan sampai sejauh mana aktiva suatu perusahaan dibiayai oleh hutang. Manajemen dengan tingkat leverage yang tinggi akan mengurangi pengungkapan sosialnya demi menghindari pemeriksaan kreditur (Swastiningrum, 2013). PenelitianAstuti (2014) menemukan bahwa Leverage berpengaruh positif terhadap pengungkapan ISR. Sedangkan penelitian Anggraini (2006) dan Swastiningrum (2013) menemukan bahwa tidak ada pengaruh leverage terhadap ISR.

H3 : Terdapat pengaruh yang negatif dan signifikan antara leverageterhadap Pengungkapan Islamic Social Reporting (ISR)

\section{HubunganUkuran Dewan Komisaris dengan Pengungkapan Islamic Social Reporting}

Ukuran dewan komisaris yaitu jumlahanggota dewan komisaris dalam suatuperusahaan (Sembiring 2005dalam Khoirudin, 2013). Dewan komisaris dan dewan pengawas syariah mempunyai fungsi yang penting dalam perbankan syariah.Dewan komisaris dan dewan pengawas syariah memiliki fungsi pengawasan terhadap manajemen.Dengan wewenang yang dimiliki, maka dewan komisaris dapat menekan manajemen untuk mengungkapkan CSR.Sedangkan DPS mempunya fungsi untuk mengawasi jalannya operasional perusahaan agar sesuai dengan prinsip syariah.Semakin besarukuran dewan komisaris, maka pengawasanakan semakin baik. Dengan pengawasan yangbaik, maka diharapkan pengungkapan Islamicsocial reporting akan semakin luas karenadapatmeminimalisir informasi yang mungkin dapatdisembunyikan oleh manajemen.Hasil temuan penelitian yang dilakukan oleh Khoirudin (2013) menemukan bahwa ukuran dewan komisaris berpengaruh terhadap pengungkapan ISR sedangkan penelitian Lestari (2013) menemukan ukuran dewan komisaris tidak berpengaruh terhadap pengungkapan ISR.

H4 : Terdapat pengaruh yang positif dan signifikan antara ukuran dewan komisaris terhadap Pengungkapan Islamic Social Reporting (ISR).

\section{Kerangka Penelitian}

Dari hubungan antar variabel diatas, dapat digambarkan kerangka kerangka pemikiran penelitian sebagai berikut :

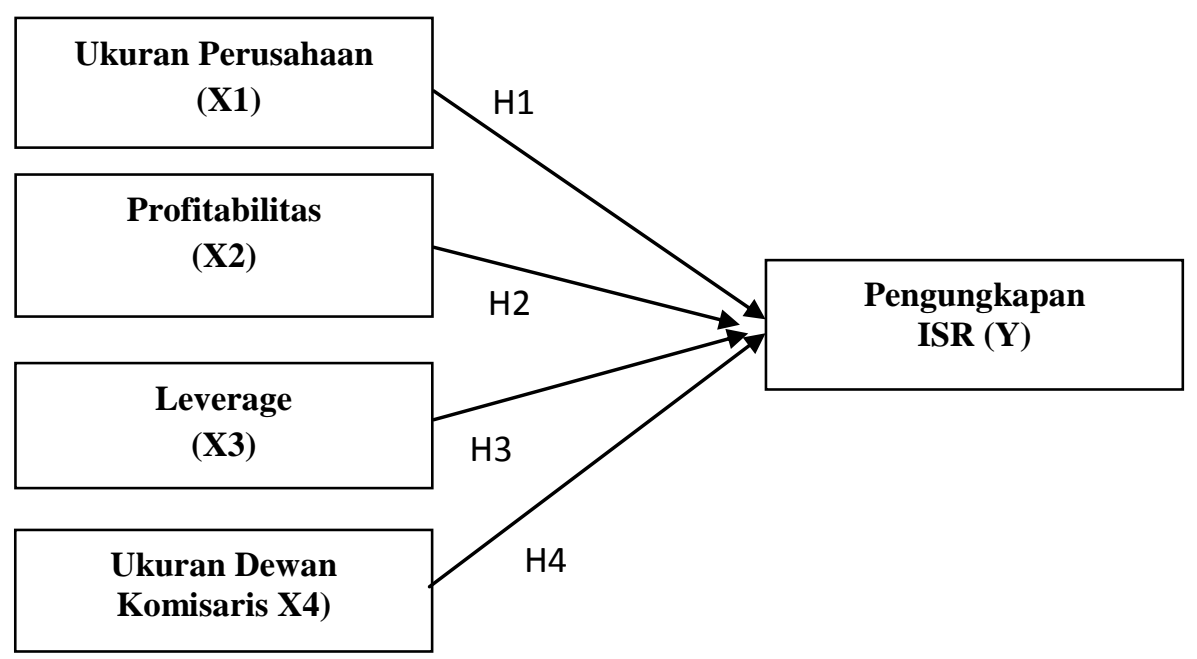

Gambar 1.Kerangka Pemikiran 


\section{METODOLOGI PENELITIAN}

\section{Variabel Penelitian dan Definisi Operasional}

Penelitian ini menggunakan variabel bebas dan variabel terikat. Variabel bebas pada penelitian ini adalah ukuran perusahaan, profitabilitas, leverage dan ukuran dewan komisaris. Sedangkan pada variabel terikat pada penelitian ini adalah pengungkapan Islamic Social Reporting (ISR).Definisi operasional variabel penelitian dijelaskan pada tabel berikut :

Tabel 1. Definisi Operasional Variabel

\begin{tabular}{|c|c|c|c|}
\hline Nama Variabel & Definisi Variabel & Indikator & Sumber \\
\hline $\begin{array}{l}\text { Ukuran perusahaan } \\
\text { (size) }\end{array}$ & $\begin{array}{ll}\text { suatu skala, dimana dapat } \\
\text { diklasifikasikan } & \text { besar } \\
\text { kecilnya perusahaan } & \end{array}$ & Size $=$ Ln. Total asset & $\begin{array}{l}\text { Widiawati dan } \\
\text { Raharja (2012). }\end{array}$ \\
\hline Profitabilitas & & $\begin{array}{lrr}\text { Return } & \text { On } & \text { Asset } \\
\text { (ROA) } & & \text { yang } \\
\text { diukur dari } & \text { laba } \\
\text { setelah } & & \text { pajak } \\
\text { dibandingkan } & \text { total } \\
\text { asset. } & & \\
\end{array}$ & Hardika (2006) \\
\hline Leverage & $\begin{array}{l}\text { Rasio yang digunakan } \\
\text { untuk } \\
\text { sejauhmana aktiva suatu } \\
\text { perusahaan dibiayai oleh } \\
\text { hutang }\end{array}$ & $\begin{array}{l}\text { Leverage }(\text { DER })= \\
\text { Total Hutang / } \\
\text { Total Ekuitas }\end{array}$ & $\begin{array}{l}\text { Firmansyah } \\
(2013)\end{array}$ \\
\hline $\begin{array}{l}\text { Ukuran dewan } \\
\text { komisaris (UDK) }\end{array}$ & $\begin{array}{lr}\text { jumlahanggota } & \text { dewan } \\
\text { komisaris } & \text { dalam } \\
\text { suatuperusahaan } & \\
\end{array}$ & $\begin{array}{l}\text { UDK= total dewan } \\
\text { komisaris }\end{array}$ & $\begin{array}{l}\text { Sembiring } \\
(2005)\end{array}$ \\
\hline $\begin{array}{l}\text { Islamic } \quad \text { Social } \\
\text { Reporting (ISR) }\end{array}$ & \begin{tabular}{lr}
\multicolumn{2}{l}{ Perluasan dari pelaporan } \\
sosial yang tidak hanya \\
berupa keinginan besar \\
dari seluruh masyarakat \\
terhadap & peranan \\
perusahaan & dalam \\
ekonomi & melainkan \\
berkaitan & dengan \\
perspektif & spiritual \\
(Haniffa,2002). &
\end{tabular} & $\begin{array}{l}\text { Disclosure Level = } \\
\text { Jumlah item yang } \\
\text { memenuhi / jumlah } \\
\text { skor maksimum } \\
\text { (Total item yang } \\
\text { digunakan } \\
\text { sebanyak } 42 \text { item } \\
\text { pengungkapan } \\
\text { sosial) }\end{array}$ & Lestari (2013) \\
\hline
\end{tabular}

\section{Populasi dan Sampel}

Populasi pada penelitian ini adalah perusahaan yang terdaftar pada Indeks Saham Syariah Indonesia periode 2012-2014. Teknik pengambilan sampel yang digunakan pada penelitian ini adalah menggunakan purposive samplingdengan kriteria : (1) Perusahaan yang terdaftar pada Indeks Saham Syariah Indonesia (ISSI) di BEI periode 2012-2014; (2) Perusahaan pada ISSI yang mengungkapkan laporan tahunan secara lengkap periode 2012-2014. 


\section{Pengujian Hipotesis}

Hipotesisdianalisis dengan menggunakan alat analisis statistik yakni analisis regresi berganda (multiple regression analysis). Dengan menggunakan software SPSS.

$$
\mathrm{Y}=\alpha+\beta_{1} \mathrm{X}_{1}+\beta_{2} \mathrm{X}_{2}+\beta_{3} \mathrm{X}_{3}+\beta_{4} \mathrm{X}_{4}+\mathrm{e}
$$

Keterangan :

$$
\begin{array}{ll}
\mathrm{Y} & =\text { Pengungkapan ISR } \\
\alpha & =\text { Konstanta } \\
\mathrm{X}_{1} & \quad=\text { Ukuran perusahaan } \\
\mathrm{X}_{2} & =\text { Profitabilitas } \\
\mathrm{X}_{3} & =\text { Leverage } \\
\mathrm{X}_{4} & =\text { Ukuran dewan komisaris } \\
\mathrm{e} & =\text { Error Term, yaitu tingkat kesalahan penduga dalam penelitian }
\end{array}
$$

\section{HASIL DAN PEMBAHASAN}

\section{Statistik Deskriptif}

Nilai rata-rata (mean) pada variabel Ukuran Perusahaan (Size) yang diukur dengan menggunakan Logaritma Natural Total Asset sebesar 14,61; nilai minimum sebesar 11,32 dan nilai maksimum sebesar 17,83.Nilai rata-rata (mean) pada variabel Profitabilitas yang diukur dengan return on total assset sebesar 4,51\%; nilai minimum sebesar $-10,45 \%$ dan nilai maksimum sebesar $36,99 \%$.

Nilai rata-rata (mean) pada variabel Leverage sebesar 1,30\%; nilai minimum sebesar -1,70\% dan nilai maksimum sebesar 6,55\%.Nilai rata-rata (mean) pada variabel Ukuran Dewan Komisaris Independen sebesar 4,19; nilai minimum sebesar 2 orang dan nilai maksimum sebesar 10 orang.Nilai rata-rata (mean) pada variabel Islamic Social Reporting(ISR) sebesar 0,42; nilai minimum sebesar 0,24 dan nilai maksimum sebesar 0,55.

\section{Hasil Uji Normalitas}

Untuk mengetahui distribusi data suatu penelitian, salah satu alat yang digunakan adalah menggunakan uji Kolmogorov Smirnov.Hasil uji Kolmogorov Smirnov pada penelitian ini dapat dilihat pada tabel berikut:

Tabel 2.Hasil Uji Kolmogorov Smirnov

One-Sample Kolmogorov-Smirnov Test

\begin{tabular}{|ll|r|}
\hline & & $\begin{array}{c}\text { Unstandardized } \\
\text { Residual }\end{array}$ \\
\hline N & Mean & 96 \\
Most Extreme Differences & $0 \mathrm{E}-7$ \\
& Std. Deviation &, 08366226 \\
& Absolute &, 135 \\
Kolmogorov-Smirnov Z & Positive &, 135 \\
Asymp. Sig. (2-tailed) & Negative &,- 097 \\
\end{tabular}

a. Test distribution is Normal.

b. Calculated from data.

Sumber : Data sekunder yang diolah, tahun 2016 
Dari tabel di atas menunjukkan bahwa nilai $\mathrm{Z}$ hitung kolmogorov smirnov untuk unstandardized residual pada model regresi dalam penelitian ini sebesar $1,321<\mathrm{Z}$ tabel $(1,96)$ dan nilai probabilitas sebesar $0,061>$ taraf signifikansi $5 \%$ atau 0,05 sehingga tergolong data yang berdistribusi normal.

\section{Hasil Uji Asumsi Klasik}

\section{Uji Multikolinearitas}

Berdasarkan pengujian uji asumsi klasik dengan asumsi multikolinieritas dengan SPSS didapatkan output sebagai berikut :

Tabel 3.Uji Asumsi Multikolinieritas

\begin{tabular}{|c|c|c|c|c|c|c|c|c|}
\hline \multicolumn{9}{|c|}{ Coefficients $^{a}$} \\
\hline \multirow{2}{*}{\multicolumn{2}{|c|}{ Model }} & \multicolumn{2}{|c|}{ Unstandardized Coefficients } & \multirow{2}{*}{$\begin{array}{c}\begin{array}{c}\text { Standardized } \\
\text { Coefficients }\end{array} \\
\text { Beta }\end{array}$} & \multirow[b]{2}{*}{$\mathrm{t}$} & \multirow[b]{2}{*}{ Sig. } & \multicolumn{2}{|c|}{ Collinearity Statistics } \\
\hline & & $B$ & Std. Error & & & & Tolerance & VIF \\
\hline \multirow[t]{5}{*}{1} & (Constant) & 204 &, 082 & & 2,475 & 015 & & \\
\hline & Size & 009 &, 006 &, 159 & 1,384 & 170 &, 627 & 1,595 \\
\hline & Profitabilitas &, 000 &, 001 &,- 019 &,- 197 & 844 & 927 & 1,079 \\
\hline & Leverage & 011 &, 006 & 171 & 1,825 & 071 & 944 & 1,059 \\
\hline & Ukuran Dewan Komisaris & 016 &, 006 &, 310 & 2,671 &, 009 & 617 & 1,621 \\
\hline
\end{tabular}

a. Dependent Variable: Islamic Social Reporting

Dari tabel 3 hasil yang diperoleh dalam angka VIF ini nilainya yaitu $<10$ yaitu untuk VIF untuk variabel Size $\left(\mathrm{X}_{1}\right)$ sebesar 1,595; VIF untuk variabel Profitabilitas $\left(\mathrm{X}_{2}\right)$ sebesar 1,079; VIF untuk variabel Leverage $\left(\mathrm{X}_{3}\right)$ sebesar 1,059 dan VIF untuk variabel Ukuran Dewan Komisaris $\left(\mathrm{X}_{4}\right)$ sebesar 1,621. Berdasarkan hasil VIF pada variabel penelitian tersebut yang bernilai < 10, maka data-data penelitian digolongkan tidak terdapat asumsi/gangguan multikolinearitas dalam model regresinya.

\section{Uji Heterokedastisitas}

Untuk menguji heteroskedastisitas dalam penelitian ini menggunakan uji glejser dengan output sebagai berikut :

Tabel 4. Uji Glejser

\begin{tabular}{|c|c|c|c|c|c|c|}
\hline \multicolumn{7}{|c|}{ Coefficients $^{a}$} \\
\hline \multirow{2}{*}{\multicolumn{2}{|c|}{ Model }} & \multicolumn{2}{|c|}{ Unstandardized Coefficients } & \multirow{2}{*}{$\begin{array}{c}\begin{array}{c}\text { Standardized } \\
\text { Coefficients }\end{array} \\
\text { Beta }\end{array}$} & \multirow[b]{2}{*}{$t$} & \multirow[b]{2}{*}{ Sig. } \\
\hline & & $\mathrm{B}$ & Std. Error & & & \\
\hline \multirow[t]{5}{*}{1} & (Constant) & .155 & .041 & & 3,746 &, 000 \\
\hline & Size &,- 006 &, 003 &,- 216 & $-1,710$ & 091 \\
\hline & Profitabilitas &, 000 &, 001 &, 086 & 830 & 409 \\
\hline & Leverage &, 003 &, 003 &, 118 & 1,153 &, 252 \\
\hline & Ukuran Dewan Komisaris &,- 002 &, 003 &,- 092 &,- 720 & 473 \\
\hline
\end{tabular}

a. Dependent Variable: Abs_Ut

Dari tabel diatas menunjukkan nilai probabilitas pada semua variabel bebas (size, profitabilitas, leverage, dan ukuran dewan komisaris) bernilai lebih besar dibandingkan taraf signifikansi 5\% atau 0,05 sehingga dapat disimpulkan tidak ada gangguan heteroskedastisitas pada model regresinya. 


\section{Uji Autokorelasi}

Berdasarkan pengujian asumsi klasik pada asumsi autokorelasi dengan SPSS didapatkan output sebagai berikut :

Tabel 5.Uji Asumsi Autokorelasi

Model Summary

\begin{tabular}{|l|c|r|r|r|r|}
\hline Model & R & R Square & $\begin{array}{c}\text { Adjusted R } \\
\text { Square }\end{array}$ & $\begin{array}{c}\text { Std. Error of } \\
\text { the Estimate }\end{array}$ & $\begin{array}{c}\text { Durbin- } \\
\text { Watson }\end{array}$ \\
\hline 1 &, $493^{\text {a }}$ &, 243 &, 210 &, 08548 & 2,022 \\
\hline
\end{tabular}

a. Predictors: (Constant), Ukuran Dewan Komisaris, Leverage, Profitabilitas, Size

b. Dependent Variable: Islamic Social Reporting

Dari tabel 5 di atas, didapatkan hasil Dw test (durbin Watson test) sebesar 2,022. Dengan diketahuinya $\mathrm{k}=4$; dan $\mathrm{n}=96$, sehingga diperoleh angka du tabel sebesar 1,758; sedangkan angka 4-du = 2,242). Hal ini berarti model regresi di atas tidak terdapat masalah autokolerasi, karena angka dw test $(1,961)$ berada diantara du tabel $(1,788)$ dan (4-du tabel=2,212), oleh karena itu model regresi ini dinyatakan layak untuk dipakai sebagai peramalan penelitian.

\section{Hasil Uji F}

Berdasarkan pengujian dengan SPSS didapatkan output anova pada tabel 6 berikut ini :

Tabel 6.Uji Anova (Uji F)

ANOVA $^{a}$

\begin{tabular}{|ll|r|r|r|r|r|}
\hline Model & & \multicolumn{1}{c|}{$\begin{array}{c}\text { Sum of } \\
\text { Squares }\end{array}$} & df & Mean Square & F & Sig. \\
\hline 1 & Regression &, 214 & 4 &, 053 & 7,321 &, $000^{\mathrm{b}}$ \\
& Residual &, 665 & 91 &, 007 & & \\
& Total &, 879 & 95 & & & \\
\hline
\end{tabular}

a. Dependent Variable: Islamic Social Reporting

b. Predictors: (Constant), Ukuran Dewan Komisaris, Leverage, Profitabilitas, Size

Dari tabel 6 di atas diketahui angka F hitung sebesar 7,321 dan angka signifikansi sebesar 0,000 lebih kecil dibandingkan taraf signifikansi $\alpha=5 \%$ artinya Size, Profitabilitas, Leverage, dan Ukuran Dewan Komisaris berpengaruh signifikan dan positif secara simultan atau bersamaan terhadap ISR (Y).

\section{Koefisien Determinasi}

Koefisien determinasi pada intinya mengukur seberapa jauh kemampuan model pada variabel bebas yaitu Size, Profitabilitas, Leverage, dan Ukuran Dewan Komisaris secara bersamasama dalam menerangkan variasi variabel terikat (ISR). 
Tabel 7.Koefisien Determinasi

Model Summary

\begin{tabular}{|l|c|r|r|r|r|}
\hline Model & R & R Square & $\begin{array}{c}\text { Adjusted R } \\
\text { Square }\end{array}$ & $\begin{array}{c}\text { Std. Error of } \\
\text { the Estimate }\end{array}$ & $\begin{array}{c}\text { Durbin- } \\
\text { Watson }\end{array}$ \\
\hline 1 &, $493^{\mathrm{a}}$ &, 243 &, 210 &, 08548 & 2,022 \\
\hline
\end{tabular}

a. Predictors: (Constant), Ukuran Dewan Komisaris, Leverage, Profitabilitas, Size

b. Dependent Variable: Islamic Social Reporting

Dari tabel 7 hasil uji regresi didapatkan angka koefisien determinasi (Adjusted $R$ Square) sebesar 0,210. Hal ini berarti bahwa ada kontribusi sebesar 21,0\% dalam memprediksi ISR yang dijelaskan oleh Size, Profitabilitas, Leverage, dan Ukuran Dewan Komisaris secara bersama-sama. Sedangkan sisanya $(100 \%-21,0 \%=79,0 \%)$ dijelaskan oleh sebab-sebab yang lain di luar variabel yang diteliti.

\section{Hasil Uji Hipotesis}

Hasil uji hipotesis t atau uji secara individual (parsial) pada variabel bebas variabel bebas : Size, Profitabilitas, Leverage, dan Ukuran Dewan Komisaris terhadap ISR (Y).

Tabel 8Uji Hipotesis

\begin{tabular}{|c|c|c|c|c|c|c|c|c|}
\hline \multicolumn{9}{|c|}{ Coefficients $^{a}$} \\
\hline & & \multicolumn{2}{|c|}{ Unstandardized Coefficients } & \multirow{2}{*}{$\begin{array}{c}\text { Standardized } \\
\text { Coefficients } \\
\text { Beta } \\
\end{array}$} & \multirow[b]{2}{*}{$t$} & \multirow[b]{2}{*}{ Sig. } & \multicolumn{2}{|c|}{ Collinearity Statistics } \\
\hline \multicolumn{2}{|c|}{ Model } & B & Std. Error & & & & Tolerance & VIF \\
\hline \multirow[t]{5}{*}{1} & (Constant) & 204 &, 082 & & 2,475 &, 015 & & \\
\hline & Size &, 009 &, 006 &, 159 & 1,384 &, 170 &, 627 & 1,595 \\
\hline & Profitabilitas &, 000 &, 001 &,- 019 &,- 197 & 844 &, 927 & 1,079 \\
\hline & Leverage &, 011 &, 006 &, 171 & 1,825 & 071 &, 944 & 1,059 \\
\hline & Ukuran Dewan Komisaris &, 016 & .006 &, 310 & 2,671 &, 009 & 617 & 1,621 \\
\hline
\end{tabular}

a. Dependent Variable: Islamic Social Reporting

\section{Pengaruh Size terhadap ISR}

Hasil perhitungan dengan menggunakan program SPSS diperoleh nilai t hitung sebesar 1,384 dan nilai probabilitas (sig.) sebesar $0,170>$ taraf signifikansi 5\% artinya Size (Ukuran Perusahaan) tidak berpengaruh signifikan terhadap ISR secara parsial.Dengan demikian hipotesis yang menyatakan bahwa Size berpengaruh signifikan dan positif terhadap ISR, tidak dapat diterima (H1 ditolak).Tidak adanya pengaruh yang signifikan ini mengindikasikan bahwa tinggi rendahnya ukuran perusahaan atau Size tidak berdampak besar pada ISR.

\section{Pengaruh Profitabilitas terhadap ISR}

Hasil perhitungan dengan menggunakan program SPSS diperoleh nilai t hitung sebesar 0,197 dan nilai probabilitas (sig.) sebesar 0,844 artinya Profitabilitastidak berpengaruh signifikan terhadap ISR secara parsial.Dengan demikian hipotesis yang menyatakan bahwa Profitabilitasberpengaruh signifikan terhadap ISR, tidak dapat diterima (H2 ditolak).Tidak adanya pengaruh yang signifikan ini mengindikasikan bahwa tinggi rendahnya Profitabilitastidak berdampak pada nilai pengungkapan ISR. 


\section{Pengaruh Leverage terhadap ISR}

Hasil perhitungan dengan menggunakan program SPSS diperoleh nilai t hitung sebesar 1,825 dan nilai probabilitas (sig.) sebesar $0,071>$ taraf signifikansi 5\% artinya Leverage tidak berpengaruh signifikan terhadap ISR secara parsial.Dengan demikian hipotesis yang menyatakan bahwa Leverage berpengaruh signifikan terhadap ISR, tidak dapat diterima (H3 ditolak). Tidak adanya pengaruh yang signifikan ini mengindikasikan bahwa tinggi rendahnya hutang perusahaan yang diperoleh perusahaan dilihat dari rasio leverage tidak berdampak pada pengungkapan ISR.

\section{Pengaruh Ukuran Dewan Komisaris Independen terhadap ISR}

Hasil perhitungan dengan menggunakan program SPSS diperoleh nilai $\mathrm{t}$ hitung sebesar 2,671 dan nilai probabilitas (sig.) sebesar 0,009 < taraf signifikansi 5\% artinya Ukuran Dewan Komisaris Independenberpengaruh signifikan terhadap ISR secara parsial.Dengan demikian hipotesis yang menyatakan bahwa Ukuran Dewan Komisaris Independenberpengaruh signifikan terhadap ISR, diterima (H4 diterima).Adanya pengaruh yang signifikan dan positif ini mengindikasikan bahwa semakin banyak ukuran dewan komisaris independenberdampak tajam pada semakin lengkapnya pengungkapan ISR.

\section{PEMBAHASAN}

\section{Pengaruh Size terhadap ISR}

Ukuran perusahaan (size)berpengaruhpada pengungkapan tanggung jawab social berbasis islam (Islamic Social Reporting). Perusahaan besar merupakan emiten yang banyak disoroti sehingga pengungkapan tanggung jawab sosialnya akan lebih besar untuk pengurangan biaya politis sebagai wujud tanggung jawab sosial perusahaan.

Hasil perhitungan menunjukkan bahwa Size (Ukuran Perusahaan) tidak berpengaruh signifikan terhadap ISR secara parsial.Dengan demikian hipotesis yang menyatakan bahwa Size berpengaruh signifikan dan positif terhadap ISR, tidak dapat diterima.Tidak adanya pengaruh yang signifikan dan positif ini mengindikasikan bahwa tinggi rendahnya ukuran perusahaan atau Size maka tidak berpengaruh penting pada pengungkapan ISR. Hasil penelitian ini mengindikasikan bahwa Perusahaan yang terdaftar pada Indeks Saham Syariah Indonesia (ISSI) yang berukuran besar belum tentu mengungkapkan informasi berbasis Islam yang lebih luas dibandingkan perusahaan pada Indeks Saham Syariah Indonesia (ISSI) yang berukuran kecil. Penelitian ini sesuai dengan penelitian yang dilakukan oleh Purnasanti M dkk (2014) menemukan hasil ukuran perusahaan tidak berpengaruh signifikan terhadap ISR.

\section{Pengaruh Profitabilitas terhadap ISR}

Profitabilitas merupakan faktor yang membuat manajemen menjadi bebas dan fleksibel untuk mengungkapkan pertanggungjawaban sosial kepada pemegang saham. Sehingga semakin tinggi tingkat profitabilitas perusahaan maka semakin besar pengungkapan informasi sosial berbasis islam (ISR).

Hasil perhitungan menunjukkan bahwa Profitabilitastidak berpengaruh signifikan terhadap ISR secara parsial.Tidak adanya pengaruh yang signifikan ini mengindikasikan bahwa tinggi rendahnya Profitabilitastidak berdampak pada pengungkapan ISR di perusahaan.Hal ini disebabkan karena perusahaan yang memiliki profitabilitas yang tinggi belum tentu banyak melakukan aktivitas sosial karena perusahaan lebih berorientasi pada laba semata. Sedangkan pada saat perusahaan memperoleh laba yang rendah, maka terdapat persepsi bahwa pengguna laporan keuangan senang untuk membaca berita baik tentang kinerja perusahaan dalam bidang sosial. Penelitian ini tidak 
sesuai dengan penelitian yang dilakukan oleh Astuti (2014), Putri dkk (2014) serta Swastiningrum (2013) menghasilkan bahwa profitabilitas tidak berpengaruh terhadap luas informasi pada pengungkapan ISR.

\section{Pengaruh Leverage terhadap ISR}

Leverage merupakan alat untuk mengukur seberapa besar perusahaan pada kreditur dalam membiayai aset perusahaan. Perusahaan yang mempunyai tingkat leverage yang tinggi berarti sangat tergantung pada pinjaman luar untuk membiayai asetnya. Sedangkan perusahaan yang mempunyai tingkat leverage rendah lebih banyak membiayai asetnya dengan modal sendiri. Tingkat leverage perusahaan dengan demikian menggambarkan resiko keuangan perusahaan. Teori keagenan memprediksi bahwa perusahaan dengan rasio leverage yang lebih tinggi akan mengungkapkan lebih banyak informasi, karena biaya keagenan perusahaan dengan struktur modal seperti itu lebih tinggi.

Hasil perhitungan menunjukkan bahwa Leverage tidak berpengaruh yang signifikan terhadap ISR secara parsial.Tidak adanya pengaruh yang signifikan ini mengindikasikan bahwa tinggi rendahnya hutang perusahaan yang diperoleh perusahaan dilihat dari rasio leverage tidak berdampak pada pengungkapan ISR. Hal ini disebabkan karena perusahaan dengan leverage yang tinggi memiliki kewajiban untuk melakukan pengungkapan yang semakin luas daripada perusahaan dengan leverage yang rendah, sehingga perusahaan akan menyediakan informasi yang lebih komprehensif mengenai pengungkapan sosialnya. Penelitian ini sesuai dengan penelitian yang dilakukan oleh Anggraini (2006) dan Swastiningrum (2013) menemukan bahwa tidak ada pengaruh leverage terhadap ISR.

\section{Pengaruh Ukuran Dewan Komisaris Independen terhadap ISR}

Dewan komisaris merupakan mekanisme pengendalian intern tertinggi, yang bertanggung jawab untuk memonitor tindakan manajemen puncak.Komposisi individu yang bekerja sebagai anggota dewan komisaris merupakan hal penting dalam memonitor aktivitas manajemen secxara efektif.Lebih jauh mereka menyatakan bahwa keefektifan dalam memonitor manajemen merupakan fungsi dari director mix (inside dan outside director). Dewan Komisaris yang terdiri dari inside dan outside directorakan memiliki akses informasi khusus berharga yang dapat membantu dewan komisaris dan menjadikannya sebagai alat efektif dalam keputusan pengedalian.

Hasil perhitungan menunjukkan bahwa Ukuran Dewan Komisaris Independenberpengaruh signifikan dan positif terhadap ISR secara parsial.Adanya pengaruh yang signifikan dan positif ini mengindikasikan bahwa semakin banyak ukuran dewan komisaris independenberdampak tajam pada pengungkapan ISR.Penelitian ini tidak sesuai dengan temuan yang dilakukan oleh Khoirudin (2013) menemukan bahwa ukuran dewan komisaris berpengaruh terhadap pengungkapan ISR.

\section{PENUTUP}

\section{Kesimpulan dan Saran}

Berdasarkan hasil analisis yang telah dilakukan terhadap hipotesis yang telah dirumuskan, maka dapat ditarik kesimpulan sebagai berikut :

1. Ukuran Dewan Komisaris Independenberpengaruh signifikan dan positif terhadap ISR secara parsial.

2. Size (Ukuran Perusahaan), Profitabilitasdan Leverage tidak berpengaruh signifikan terhadap ISR secara parsial. 
Berdasarkan hasil penelitian di atas, maka implikasi yang dapat diajukan pada penelitian ini yaitu :

1. Bagi perusahaan, penelitian ini diharapkan mampu menyadarkan pimpinan perusahaan akan pentingnya Islamic Social Reporting (ISR) dan dari temuan penelitian menunjukkan bahwa perusahaan yang memiliki komisaris independen relatif banyak akan semakin tinggi dalam pengungkapan tanggung jawab sosial berbasis Islam (ISR) dibandingkan perusahaan dengan jumlah komisaris independen yang relatif sedikit.

2. Bidang akademis, penelitian ini sangat berguna untuk menambah pengetahuan, dalam lingkup pendidikan formal yaitu untuk bidang akademis karena dapat memperluas wawasan tentang pentingnya kelengkapan dan luas pengungkapan laporan keuangan berbasis Islam (ISR) yang dapat digunakan sebagai pedoman dalam proses belajar mengajar.

\section{Keterbatasan dan Agenda Riset Mendatang}

Dari keempat variabel bebas dalam penelitian ini yang berpengaruh terhadap Islamic Social Reporting (ISR) hanya Ukuran Dewan Komisaris. Sedangkan variabel bebas lainnya tidak berpengaruh terhadap ISR. Pengaruh variabel bebas terhadap variabel terikat hanya mampu menjelaskan sebesar $21,0 \%$ sehingga perlu menambah variabel bebas lain.

Untuk penelitian selanjutnya perlu melakukan penelitian dengan menggunakan variabel bebas lain yang berpotensi berpengaruh terhadap ISR, misalnya rasio aktivitas (total asset turnover, inventory turnover), rasio pertumbuhan (price earning ratio), rasio investasi (Investment Opportinity Set) dan rasio keuangan lainnya.

\section{DAFTAR REFERENSI}

Astuti, Tri Puji.(2014), Faktor - Faktor Yang Mempengaruhi Pengungkapan Islamic Social Reporting (ISR) Pada Bank Syariah Di Indonesia.Jurnal Publikasi Universitas Muhammadiyah Surakarta.

Firmansyah, Irman. (2013). Tanggungjawab Sosial Perbankan Syariah Suatu Kajian dalam Pengungkapan Laporan Tahunan menurut Pandangan Islam (Studi di Indonesia dan Malaysia).Bandung : Penerbit Mujahid Pres.

Fr. Reni. Retno Anggraini. (2014).Pengungkapan Informasi Sosial danFaktor-Faktor yang Mempengaruhi Pengungkapan Informasi Sosial dalam Laporan Keuangan Tahunan (StudiEmpiris pada Perusahaan-Perusahaan yang terdaftar BursaEfek Jakarta.Simposium Nasional Akuntansi.

Haniffa, R. (2002). Social Reporting Disclosure: An Islamic Perspective. Indonesian Management Research, 128-146.

Khoirudin, Amirul, (2013).Corporate Governance Dan Pengungkapan Islamic Social Reporting Pada Perbankan Syariah Di Indonesia.Accounting Analysis Journal Vol. 2 No. 2

Lestari, Puji. (2013). Determinants Of Islamic Social Reporting In Syariah Banks: Case Of Indonesia. International Journal of Business and Management Invention Vol. 2 Issue 10.

Putri, Tria Karina dkk. (2014). Faktor-Faktor Yang Mempengaruhi Islamic Social Reporting Perusahaan-Perusahaan Yang Terdaftar Pada Indeks Saham Syariah Indonesia (ISSI) Tahun 2011-2012. Diponegoro Journal of Accounting Vol. 3 No. 2.

Purnasanti, Aldehita M dkk. (2014). Analisis Faktor - Faktor Yang Mempengaruhi Pengungkapan Islamic Social Reporting (ISR). SNA 17 Mataram Lombok 
Sembiring, E. R. (2003). Kinerja Keuangan, Political Visibility, Ketergantungan Pada Hutang, dan Pengungkapan Tanggung Jawab Sosial Perusahaan. Simposium Nasional Akuntansi.

Sembiring, Eddy Rismanda. (2005). "Perkembangan Corporate Social Responsibility di Indonesia. Simposium Nasional Akuntansi 8. Solo.

Swastiningrum, Desta, (2013). Pengaruh Ukuran Perusahaan, Profitabilitas, Leverage, dan Tipe Kepemilikan terhadap Islamic Social Reporting Laporan Tahunan yang Terdapat pada Perbankan Syariah Periode 2010-2012. Jurnal Universitas Islam Negeri Sunan Kalijaga Yogyakarta.

Widiawati, Septi dan Surya Raharja.(2012). Analisis Faktor-Faktor yang Mempengaruhi Islamic Social Reporting Perusahaan - Perusahaan Yang Terdapat Pada Daftar Efek Syariah Tahun 2009-2011. Diponegoro Journal Of Accounting. Volume 1, Nomor 2, Tahun 2012, Halaman 1-15. 